\title{
PENGARUH INTELLECTUAL CAPITAL TERHADAP KINERJA KEUANGAN PADA SUBSEKTOR INDUSTRI HOTEL, RESTORAN DAN PARIWISATA
}

\author{
Wayan Anggara Wijaya ${ }^{1}$ \\ I Gusti Bagus Wiksuana ${ }^{2}$ \\ ${ }^{1,2}$ Fakultas Ekonomi dan Bisnis Universitas Udayana (UNUD), Bali, Indonesia \\ email: anggarawjy@gmail.com
}

\begin{abstract}
ABSTRAK
Kinerja keuangan perusahaan merupakan permasalahan klasik yang dimiliki oleh sebuah perusahaan. Setiap perusahaan memiliki tanggung jawab kepada stakeholder untuk dapat menstabilkan serta meningkatkan kinerja keuangan. Dengan adanya teori RBV dan studi mengenai faktor- faktor yang mempengaruhi kinerja keuangan perusahaan di masa kini menciptakan perkembangan pada sudut pandang sumber daya yaitu perspektif intellectual capital. Perspektif tersebut memungkinkan perusahaan dapat mengetahui sumber daya yang strategis dalam meningkatkan kinerja keuangan perusahaan. Penelitian memiliki tujuan untuk menjelaskan pengaruh masing -masing komponen VAIC ${ }^{\text {TM }}$ dan intellectual capital secara keseluruhan terhadap ROE. Penentuan sampel dengan sampling jenuh dengan sampel penelitian berjumlah 17 perusahaan pada subsektor industri hotel, restoran dan pariwisata di BEI tahun 2012-2015. Teknik analisis dengan metode regresi linier berganda. Temuan hasil penelitian yaitu hanya structural capital efficiency yang tidak berpengaruh signifikan terhadap kinerja keuangan. Manajer dapat meningkatkan penggunaan modal struktural dalam kegiatan operasional perusahaan guna meningkatkan pengaruhnya terhadap kinerja keuangan perusahaan.
\end{abstract}

Kata kunci: kinerja keuangan, intellectual capital, teori RBV

\begin{abstract}
Financial performance is classical problem that every corporate has. Every corporate has a responsibility to the stakeholder for stabilize and improve their own financial performance. $R B V$ theory and others study thats concern on financial performance created the point of view of resource that is perspective of intellectual capital. That's perspective are possible for corporate to understand the strategic resource on improve their own financial performance. The purpose of this research is to determine the influence of human capital efficiency, capital employed efficiency, structural capital efficiency and overall of intellectual capital toward corporate financial performance. Research focused on hotel industry in BEI during 2012-2015. Sampling technique applied is saturation sampling method and final sample are 17 companies. Multiple linear regression chosen to analyze the data. The study indicate only variable structural capital efficiency has no significant effect on financial performance. Managers can improve the used of structural capital to increase the influence on corporate financial performance
\end{abstract}

Keywords: financial performance, intellectual capital, RBV Theory 
Wayan Anggara Wijaya, Pengaruh Intellectual Capital Terhadap...

\section{PENDAHULUAN}

Penggambaran mengenai kondisi finansial sebuah perusahaan dapat dilakukan dengan mempergunakan perhitungan rasio-rasio kinerja keuangan untuk menilainya (Subkhan dan Citraningrum, 2010). Menurut Wiagustini (2014 : 86) dalam menganalisis kinerja keuangan terdapat analisis rasio melalui profitabilitas yang mencerminkan kemampuan perusahaan untuk menghasilkan laba. Salah satu rasio keuangan dalam aspek profitabilitas adalah return on equity atau yang dikenal dengan tingkat keuntungan yang dihasilkan oleh modal sendiri. Di masa kini dimana masa perkembangan informasi yang sangat cepat faktor pengetahuan, teknologi informasi, dan intellectual capital menjadi prioritas untuk diaplikasikan perusahaan (Ozkan et al., 2016; Yalama, 2013). Teori resourcebased view mengasumsikan perusahaan yang memiliki perbedaan sumber daya yang dimiliki memungkinkan dalam pengembangan strategi yang berbeda (Grant, 1991; Bontis et al., 2015). Isu ini dianggap menarik bagi para manajer perusahaan untuk meningkatkan eksistensi perusahaan (Tan et al., 2007). Andreas Budihardjo (2016 : 58) menyatakan bahwa dalam meningkatkan kinerja keuangan dalam perusahaan terdapat 2 komponen besar yang mempengaruhi yaitu financial capital dan intellectual capital. Dalam financial capital tersebut didalamnya modal fisik yaitu seperti jumlah aset tak bergerak. Tanpa adanya modal fisik ini intellectual capital tidak dapat dijalankan secara optimal dalam perusahaan.

Pengelompokan elemen-elemen intellectual capital yang paling dikenal yaitu yang diterangkan oleh Edvinsson (1997) yakni terdapat setidaknya tiga komponen penting didalamnya yaitu human capital atau manusia, structural 
capital yaitu strukturalnya, dan relational capital yaitu hubungan pegawai dan pelanggan. Pengukuran intellectual capital yang diakui secara universal yakni salah satunya pengukuran yang dikemukakan Pulic pada tahun 1998. Model ini menggunakan nilai tambah yang dihasilkan, bersumber dari laporan keuangan untuk mengetahui nilai dari intellectual capital. Nilai tambah dalam perhitungan ini tidak menghitung relational capital, karena relational capital dianggap telah masuk dalam human capital. Nilai tambah ini disebut Value Added Intellectual Coefficient atau VAIC ${ }^{\text {TM }}$ (Pulic, 1998; 2004).

Dalam perhitungan VAIC ${ }^{\mathrm{TM}}$ ini bagian yang termasuk di dalamnya yaitu, yang pertama Human Capital Efficiency yakni komponen intellectual capital yang dihasilkan dari kemampuan yang dimiliki perusahaan yang berasal dari kemampuan karyawannya. Kedua, Capital Employed Efficiency yakni efisiensi modal usaha yang dipilih untuk mewakili komponen modal fisik dalam perusahaan. Ketiga Structural Capital Efficiency yakni komponen intellectual capital yang berasal dari infrastruktur pendukung pekerjaan, proses ataupun database perusahaan.

Beberapa penelitian di berbagai negara yang berfokus pada kinerja keuangan yang dipengaruhi oleh intellectual capital serta menggunakan model VAIC ${ }^{\text {тм }}$ antara lain di Singapura (Tan et al., 2007), Pakistan (Kharal et al., 2014), di Turki (Ozkan et al., 2016), Malaysia (Khalique et al., 2013), Indonesia (Ciptaningsih, Tri 2013); (Pramelasi 2010) serta (Salim dan Karyawati 2013) dan penelitian di Serbia (Bontis et al., 2015). Dari seluruh penelitian diatas menghasilkan hasil penelitian yang berbeda. 
Wayan Anggara Wijaya, Pengaruh Intellectual Capital Terhadap...

Tabel 1. Ringkasan Hasil Penelitian Pengaruh Intellectual Capital Terhadap Kinerja Keuangan Perusahaan

\begin{tabular}{|c|c|c|}
\hline Peneliti & Metode & Hasil \\
\hline $\begin{array}{l}\text { Tan et al., } \\
\text { (2007) }\end{array}$ & $\begin{array}{l}\text { VAIC } \\
\text { Linier }\end{array}$ & $\begin{array}{l}\text { Kinerja keuangan perusahaan positif } \\
\text { signifikan dipengaruhi oleh intellectual } \\
\text { capital }\end{array}$ \\
\hline $\begin{array}{l}\text { Kharal et al., } \\
\qquad(2014)\end{array}$ & $\begin{array}{l}\text { VAIC }{ }^{\mathbf{T}} \text {, Korelasi, } \\
\text { Regresi linier }\end{array}$ & $\begin{array}{l}\text { Intellectual capital memiliki korelasi yang } \\
\text { tinggi dengan kinerja keuangan kecuali } \\
\text { Sales Growth. Intellectual capital } \\
\text { berpangaruh positif signifikan terhadap } \\
\text { kinerja keuangan }\end{array}$ \\
\hline $\begin{array}{l}\text { Ozkan et al., } \\
\text { (2016) }\end{array}$ & $\begin{array}{l}\text { VAIC'т , Korelasi, } \\
\text { Regresi linier }\end{array}$ & $\begin{array}{l}\text { Komponen dari modal intelektual } \\
\text { mempengaruhi kinerja keuangan secara } \\
\text { signifikan }\end{array}$ \\
\hline $\begin{array}{l}\text { Khalique et al., } \\
\text { (2013) }\end{array}$ & $\begin{array}{l}\text { VAICTM, Korelasi, } \\
\text { Regresi linier berganda }\end{array}$ & $\begin{array}{l}\text { Pada sektor perbankan syrariah di Malaysia, } \\
\text { kinerja keuangan signifikan dipengaruhi } \\
\text { oleh intellectual capital }\end{array}$ \\
\hline $\begin{array}{l}\text { Ciptaningsih, } \\
\text { Tri (2013) }\end{array}$ & $\begin{array}{l}\text { VAIC }{ }^{\mathbf{T M}}, \text { Korelasi, } \\
\text { Regresi linier berganda }\end{array}$ & $\begin{array}{l}\text { VAIC Tм tidak memiliki pengaruh terhadap } \\
\text { kinerja keuangan }\end{array}$ \\
\hline $\begin{array}{l}\text { Pramelasi } \\
\text { (2010) }\end{array}$ & $\begin{array}{l}\text { VAIC }{ }^{\mathbf{T M}} \text {, Regresi linier } \\
\text { berganda }\end{array}$ & $\begin{array}{l}\text { Nilai VAIC }{ }^{\text {TM }} \text { tidak berpengaruh terhadap } \\
\text { kinerja keuangan perusahaan }\end{array}$ \\
\hline $\begin{array}{l}\text { Salim dan } \\
\text { Karyawati } \\
\quad(2013)\end{array}$ & $\begin{array}{l}\text { VAIC } \\
\text { berganda }\end{array}$ & $\begin{array}{l}\text { Hanya komponen SCE yang tidak } \\
\text { berpengaruh signifikan terhadap kinerja } \\
\text { keuangan }\end{array}$ \\
\hline $\begin{array}{l}\text { Bontis et al., } \\
\quad(2015)\end{array}$ & $\begin{array}{l}\text { VAIC } \\
\text { Regresi linier berganda }\end{array}$ & $\begin{array}{l}\text { Industri Hotel di Serbia sangat dipengaruhi } \\
\text { oleh modal fisik. Komponen HCE dan SCE } \\
\text { tidak mempengaruhi kinerja keuangan } \\
\text { secara signifikan }\end{array}$ \\
\hline
\end{tabular}

Sumber: penelitian empiris terdahulu

Dengan adanya hasil penelitian yang masih belum konsisten pada tabel 1 , terdapat indikasi adanya research gap dan ini membuka peluang untuk dilakukannya penelitian kembali. Penelitian dilakukan pada subsektor industri hotel, restoran dan pariwisata. Hal ini dikarenakan subsektor ini dianggap unik dan dapat mewakili industri jasa yang dimana industri ini memiliki permasalahan mengenai kinerja keuangan dan menjadi isu pokok dalam pelaksanaan penelitian. Kinerja keuangan yang diproksikan oleh ROE karena rasio ini memberikan infomasi penting bagi investor untuk mengetahui laba yang dihasilkan dari modal sendiri yang dimiliki perusahaan selain itu juga ROE pada subsektor ini 
mengalami fluktuasi bahkan cenderung menurun dari periode tahun 2012 hingga tahun 2015.

\section{TELAAH LITERATUR DAN PENGEMBANGAN HIPOTESIS}

Menurut teori RBV yang dikemukakan oleh Madhani (2009), sumber daya dapat secara umum mencakup proses organisasi, informasi dan pengetahuan yang dikendalikan oleh perusahaan dalam penerapan strategi bisnis perusahaan. Barney (1991) mengklasifikasikan sumber daya ke dalam tiga hal, yaitu sumber daya fisik, sumber daya manusia, serta sumber daya organisasi. Wernerfelt (1984) mengemukakan apabila perusahaan dapat memegang, mengontrol, dan mempergunakan aset serta modal yang strategis maka dapat meningkatkan keunggulan bersaing perusahaan. Perusahaan yang dapat memanfaatkan sumber daya dan sumber daya tersebut memberikan keuntungan terhadap perusahaan dapat dikatakan bahwa sumber daya tersebut memiliki keunggulan (Belkaoui, 2003). Chen et al., (2005) menyatakan bahwa teori RBV terbatas hanya melihat sumber daya secara statis seperti jumlah secara kuantitasnya, dan tidak mampu dalam mendefinisikan pertambahan nilai dari sumber daya tak berwujud. Perspektif intellectual capital membantu dalam mendeskripsikan pengukuran pertambahan nilai yang dihasilkan oleh sumber daya tak berwujud.

Sebagai emiten pada pasar modal perusahaan pada umumnya menerbitkan kinerja keuangan sebagai salah satu tanggung jawab terhadap pemegang saham (Arifin, 2016). Menurut Wijaya (2012) kinerja keuangan merupakan indikator seberapa besar tingkat laba yang diperoleh perusahaan. Rasio kinerja yaitu ROE 
merupakan rasio profitabilitas yang mengukur hasil dari modal sendiri atau ekuitas yang dimiliki perusahaan (Salim dan Karyawati, 2013). Kegunaan ROE adalah mengukur efisiensi keuangan suatu perusahaan dan dapat membandingkan profitabilitas antar perusahaan (Arifin, 2016). Perhitungannya dengan membagi laba bersih setelah dikurangi pajak (earning after tax) dengan jumlah ekuitas atau $\frac{E A T}{E k \text { witas }}$ (Pramelasari, 2010). Perusahaan yang dapat memiliki kinerja keuangan yang baik jika sukses dalam pengelolaan sumber daya yang dimiliki (Rambe, 2012).

Semakin banyak perusahaan yang menginvestasikan kekayaannya pada pengembangan dan pelatihan karyawan, hubungan kepada pelanggan, serta software komputer sebagai wujud intellectual capital (Zéghal and Maaloul, 2010). Aset tak berwujud, manusia dan infrastruktur penunjang pekerjaan memberikan peluang perusahaan untuk menjalankan fungsi intellectual capital untuk menciptakan pertambahan nilai (Brooking, 2010). IC adalah kekuatan sumber daya organisasi dalam menciptakan, dan mengimplementasikan pengetahuan sebagai elemen nilai tambah (Rupidara, 2005). Intellectual capital didefinisikan sebagai perbedaan nilai pasar dengan biaya pengganti asetnya hal tersebut dilakukan untuk mengukur keahlian dan pengetahuan yang dimiliki perusahaan yang sulit dikuantifikasikan secara langsung (Kanchana and Mohan, 2017). Menurut Kweh et al., (2013) nilai tambah yang dihasilkan oleh IC dimulai dari informasi-informasi yang disusun menjadi pengetahuan, dan pengetahuan yang didapatkan tersebut yang ditranformasikan menjadi IC. Model Pulic yang dikenal dengan sebutan VAIC ${ }^{\text {TM }}$ mengukur modal intelektual tidak secara langsung 
namun dengan mengusulkan koefisien Value Added Intellectual Coefficient (VAIC ${ }^{\mathrm{TM}}$ ) untuk memberikan informasi perhitungan mengenai seberapa besar efisiensi penciptaan nilai tambah dari aset berwujud dan tidak berwujud dalam suatu perusahaan (Pulic, 1998; 2004). Metode VAICTM menghitung seberapa besar efisien penggunaan tiga jenis input perusahaan yaitu, human capital efficiency, capital employed efficiency dan structural capital efficiency. Uniknya perhitungan ini tidak melihat beban yang dihasilkan karyawan namun lebih dilihat sebagai modal perusahaan.

Perhitungan pertama dilakukan dengan mengurangi total pemasukan dan pendapatan lain dari perusahaan (OUT) dengan beban penjualan serta beban lainnya diluar gaji dan tunjangan karyawan (IN) untuk mengetahui nilai tambah atau value added yang dihasilkan perusahaan (VA).

$$
\mathrm{VA}=\text { OUT-IN }
$$

Perhitungan kedua yakni menghitung Human Capital Efficiency. HCE menunjukkan kontribusi yang dibuat oleh setiap rupiah yang diinvestasikan dalam Human Capital didalam meningkatkan nilai tambah (VA). HCE diukur dengan membagi nilai VA yang didapat dengan gaji dan tunjangan karyawan sebagai proksi Human Capital (HC).

$$
\mathrm{HCE}=\mathrm{VA} / \mathrm{HC}
$$

Perhitungan ketiga yakni menghitung Capital Employed Efficiency CEE merupakan efisiensi penggunaan Capital Employed terhadap Value Added atau nilai tambah yang dihasilkan. Perhitungan dilakukan dengan membagi nilai VA dengan total modal sendiri atau ekuitas perusahaan sebagai proksi CE 


\section{$\mathrm{CEE}=\mathrm{VA} / \mathrm{CE}$}

Perhitungan keempat yakni menghitung seberapa besar Structural Capital Efficiency. SCE menghitung jumlah modal struktural yang dibutuhkan untuk menghasilkan satu rupiah dari VA dan merupakan indikasi bagaimana keberhasilan SC dalam penciptaan nilai. Perhitungan dilakukan dengan mengurangi nilai VA dengan HC untuk mendapatkan nilai Structural Capital (SC). Untuk mendapatkan nilai SCE atau Structural Capital Efficiency dilakukan dengan membagi nilai SC yang didapatkan dengan VA

$$
\mathrm{SCE}=\mathrm{SC} / \mathrm{VA}
$$

Perhitungan terakhir yakni menghitung Value Added Intellectual Coefficient. VAIC ${ }^{\mathrm{TM}}$ menginformasikan bagaimana kemampuan intelektual organisasi secara keluruhan dengan menjumlah ketiga komponen. Perhitungan dilakukan dengan menambah seluruh komponen yang telah dihitung sebelumnya.

$$
\begin{gathered}
\text { VAIC }^{\mathrm{TM}}=\mathrm{HCE}+\mathrm{CEE}+\mathrm{SCE} \\
\text { Human capital efficency (HCE) adalah elemen penopang intellectual }
\end{gathered}
$$
capital. Dimana modal manusia ini termasuk di dalamnya yaitu pengetahuan serta inovasi yang dapat meningkatkan daya saing dan tentunya menciptakan keunggulan yang kompetitif. Menurut Bontis et al., (2015) pengetahuan adalah elemen yang kuat dalam menciptakan keunggulan kompetitif terutama pada era globalisasi. Pengetahuan dan teknologi informasi memungkinkan perusahaan untuk menciptakan kombinasi optimal dari modal berwujud dan tidak berwujud dalam meningkatkan finansial perusahaan (Brooking, 2010). 
Penelitian empiris sebelumnya yang berfokus pada kinerja keuangan oleh Irene et al., (2009) pada perusahaan sektor perbankan Malaysia menunjukan modal manusia memiliki peranan dalam meningkatkan kinerja keuangan. Hasil juga ditemukan dalam penelitian Kamal et al., (2012) pada industri perbankan Malaysia, hasil penelitian menunjukkan ROE dipengaruhi secara signifikan oleh modal manusia atau HCE. Hasil yang sama ditemukan juga oleh Muthater dan Prasetyo (2014).

H1: Human Capital Efficiency (HCE) berpengaruh positif signifikan terhadap Return On Equity (ROE)

Tentu saja komponen fisik yaitu capital employed efficiency (CEE) tidak kalah penting juga dalam meningkatkan kinerja keuangan perusahaan. Hal ini dikarenakan CEE adalah komponen VAIC ${ }^{\text {TM }}$ yang mencerminkan efisiensi modal fisik perusahaan. Dalam modal fisik terdapat modal finansial yang dimana dapat meningkatkan kinerja keuangan apabila dikelola dengan baik (Andreas Budihardjo 2016 : 58)

Penelitian empiris mengenai hubungan antara CEE dengan ROE sebagai proksi kinerja keuangan memiliki pengaruh yang signifikan diantaranya penelitian Bontis et al., (2015) dengan obyek Industri Hotel di Serbia, Aritonang dkk. (2016) pada perusahaan non bank Indonesia di BEI, serta Muthather dan Prasetyo (2014). Penelitian diatas menunjukkan bahwa semakin meningkatnya nilai CEE maka akan meningkatkan nilai ROE perusahaan tersebut. Dalam penelitian tersebut juga menyebutkan modal fisik memiliki pengaruh tertinggi dalam meningkatkan profitabilitas. 
H2: Capital Employed Efficiency berpengaruh positif signifikan terhadap Return On Equity (ROE)

Wahdikorin (2010) menyatakan bahwa structural capital adalah sarana yang mendukung manusia dalam meningkatkan kinerja keuangan perusahaan. Oleh karena itu, structural capital efficiency (SCE) dipandang penting dalam menopang kinerja keuangan perusahaan. Selain itu menurut Rusmalia Dewi dan Setyowati (2015) dengan adanya structural capital yang baik seperti budaya organisasi di sebuah perusahaan dapat memungkinkan perusahaan untuk belajar dan mencoba sesuatu hal yang lain.

Hal ini diperkuat dengan penelitian empiris yang dilakukan di Indonesia yaitu penelitian Muthater dan Prasetyo (2014) bahwa SCE berpengaruh positif signifikan terhadap ROE. Penelitian lain yang memiliki hasil yang sama yaitu Gozali dan Hatane (2014) menemukan bahwa SCE memiliki pengaruh positif dan signifikan terhadap kinerja keuangan perusahaan. Ramadhani dkk. (2014) juga menemukan modal struktural memiliki pengaruh signifikan terhadap kinerja keuangan.

H3: Structural Capital Efficiency (SCE) berpengaruh positif signifikan terhadap Return On Equity (ROE)

Value Added Intellectual Coefficient (VAIC ${ }^{\mathrm{TM}}$ ) adalah proksi dari intellectual capital secara keseluruhan yang didalamnya terdapat komponenkomponen yaitu CEE, HCE dan SCE. Pulic (1998; 2004) menggunakan proksi VAIC ${ }^{\text {TM }}$ dalam mengetahui tingkat efisiensi penggunaan intellectual capital 
dalam perusahaan. Dengan adanya efisiensi penggunaan intellectual capital akan memberikan pengaruh terhadap kinerja keuangan

Penelitian terdahulu mengindikasikan bahwa pengelolaan IC dapat mempengaruhi kinerja keuangan perusahaan. Penelitian-penelitian empiris tersebut yakni Tan et al., (2007) menemukan VAICTM memiliki pengaruh yang positif dan signifikan terhadap kinerja keuangan Kharal et al., (2014) serta Gozali dan Hatane (2014) juga menemukan hal yang sama.

H4: Value Added Intellectual Coefficient (VAIC ${ }^{\mathrm{TM}}$ ) berpengaruh positif signifikan terhadap Return On Equity (ROE)

Berdasarkan kajian teoritis dan empiris terdahulu, dapat disusun suatu kerangka konseptual penelitian yang ditunjukkan pada Gambar 1. Kerangka konseptual ini disusun untuk dapat menjelaskan tujuan dari penelitian ini dimana mengukur pengaruh komponen intellectual capital terhadap kinerja keuangan.

Gambar 1. Kerangka Konseptual

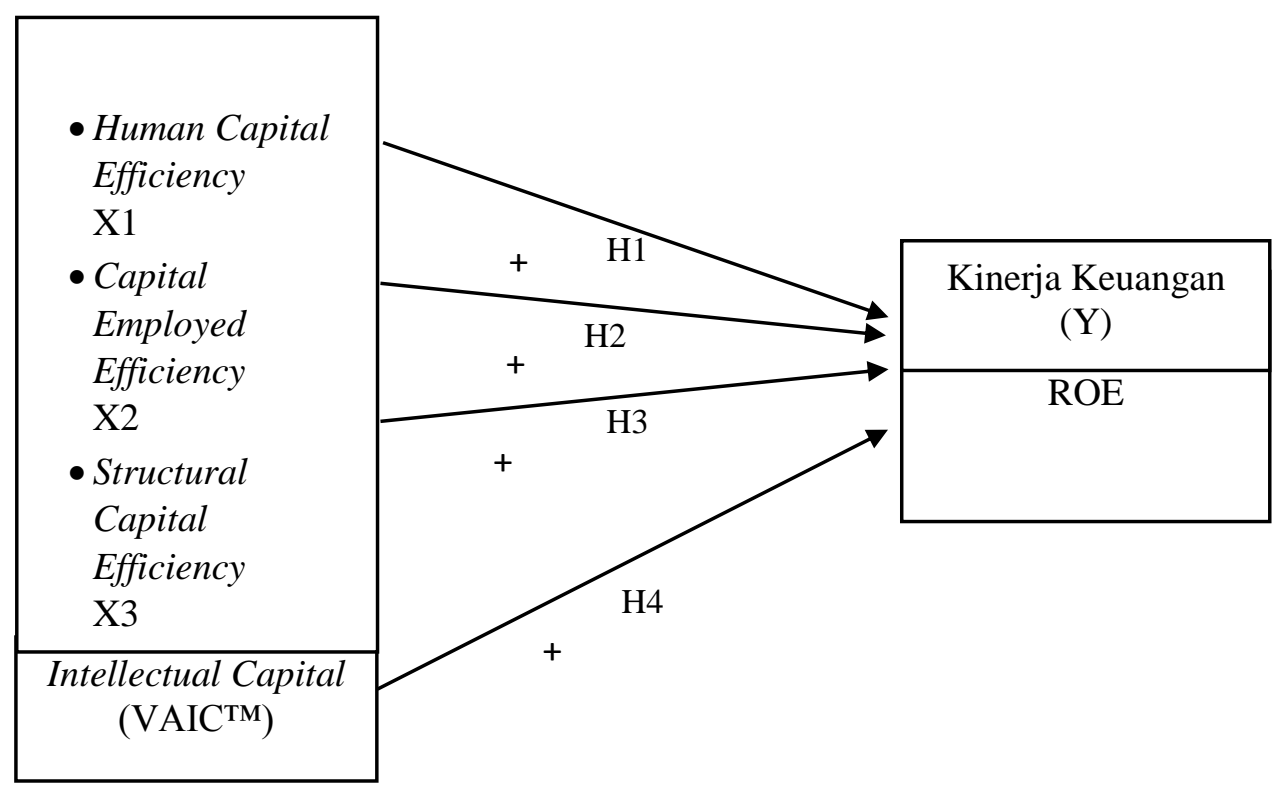

Sumber: Penelitian terdahulu 


\section{METODE PENELITIAN}

Metode yang digunakan yaitu pendekatan kuantitatif dan bersifat asosiatif kausal yang dimana menguji pengaruh Human Capital Efficiency sebagai proksi modal manusia (X1), Capital Employed Efficiency sebagai proksi modal fisik (X2), Structural Capital Efficiency sebagai proksi modal struktural (X3) dan VAIC $^{\text {TM }}$ sebagai modal intelektual secara keseluruhan terhadap Kinerja Keuangan yang diproksi oleh ROE (Y). Penelitian ini mempergunakan data sekunder yang dengan pengukuran model VAIC ${ }^{\mathrm{TM}}$ yang dilihat dari laporan keuangan perusahaan go-publik subsektor hotel, restoran dan pariwisata di Indonesia periode tahun 2012-2015 pada Bursa Efek Indonesia lalu diolah demi memenuhi kriteria penelitian. Sumber data diperoleh dari BEI yang dapat diakses melalui situs www.idx.co.id yang dipublikasikan berupa data laporan keuangan yang telah diaudit pada perusahaan go-publik subsektor industri hotel, restoran dan pariwisata periode tahun 2012-2015.

Pemilihan populasi menggunakan kriteria tertentu untuk mendapatkan populasi yang dirasa dapat menjelaskan tujuan penelitian, kriteria populasi penelitian yakni perusahaan di BEI pada subsektor industri hotel, restoran dan pariwisata serta menerbitkan laporan keuangan secara pada periode tahun 20122015. Berdasarkan paparan kriteria tersebut populasi didapatkan sebanyak 17 perusahaan dari 25 observasi. Hal ini dikarenakan beberapa perusahaan tidak memenuhi kriteria populasi yang disebutkan.

Metode penentuan sampel digunakan teknik sensus dengan sampel jenuh yaitu menggunakan seluruh populasi sebagai sampel. Pemilihan teknik ini karena 
jumlah populasi kurang dari 30 dan agar dapat menjelaskan seluruh populasi. Maka dari itu sampel yang didapatkan sebanyak 17 perusahaan Go-Publik di BEI pada subsektor hotel, restoran dan pariwisata periode tahun 2012-2015. Teknik pengumpulan data yaitu dengan metode observasi non partisipan. Analisis dilakukan dengan program Microsoft Excel dan program SPSS versi 23.

Sebelum melakukan analisa regresi linier berganda model diharuskan melakukan Uji Asumsi Klasik yakni antara lain Uji Normalitas, Uji Multikolinearitas, Uji Heterokedastisitas dan Uji Autokorelasi karena menggunakan data deret waktu. Persamaan regresi linier berganda dirumuskan secara matematis sebagai berikut:

$$
\mathrm{ROE}_{\mathrm{it}}=\alpha+\beta_{1} \mathrm{HCE}_{\mathrm{it}}+\beta_{2} \mathrm{CEE}_{\mathrm{it}}+\beta_{3} \mathrm{SCE}_{\mathrm{it}}+\mathrm{e}
$$

$$
\begin{array}{ll}
\text { Keterangan: } & \\
\alpha & =\text { Konstanta } \\
\beta & =\text { Koefisien Regresi } \\
\mathrm{ROE}_{\mathrm{it}} & =\text { ROE perusahaan } \mathrm{i} \text { tahun ke } \mathrm{t} \\
\mathrm{HCE}_{\mathrm{it}} & =\text { HCE perusahaan } \mathrm{i} \text { tahun ke } \mathrm{t} \\
\mathrm{CEE}_{\mathrm{it}} & =\text { CEE perusahaan } \mathrm{i} \text { tahun ke } \mathrm{t} \\
\mathrm{SCE}_{\mathrm{it}} & =\mathrm{SCE} \text { perusahaan } \mathrm{i} \text { tahun ke } \mathrm{t} \\
\mathrm{e} & =\text { Error }
\end{array}
$$

Hasil keluaran dari model regresi yang dihasilkan juga dilengkapi dengan uji ketepatan model atau Uji F, Uji t untuk menguji hipotesis penelitian apabila nilai signifikansi < dari nilai 0,05 maka hipotesis alternatif diterima dan Uji determinasi $\mathrm{R}^{2}$ untuk menguji seberapa besar variabel dependen dapat dijelaskan 
oleh variabel independepen dalam model penelitian, dengan ukuran kepercayaan sebesar $95 \%$ atau $\alpha$ sebesar $5 \%$ atau 0,05 .

\section{HASIL DAN PEMBAHASAN}

Data statistik deskriptif memberikan informasi mengenai nilai minimum, nilai maksimum dan nilai rata-rata variabel penelitian. Hasil statistik deskriptif dalam tabel 2.

Tabel 2. Hasil Analisis Statistik Deskriptif

\begin{tabular}{lcrrrr}
\hline & N & Minimum & Maximum & \multicolumn{1}{l}{ Mean } & Std. Deviation \\
\hline HCE & 68 & $-2,1068$ & 19,7318 & 2,587424 & 2,8558642 \\
CEE & 68 & $-0,3572$ & 1,4296 & 0,341138 & 0,3226475 \\
SCE & 68 & $-2,2397$ & 2,0704 & 0,421950 & 0,5555788 \\
VAIC & 68 & $-1,7684$ & 21,0910 & 3,350500 & 3,0466651 \\
ROE & 68 & $-52,62$ & 35,13 & 5,8109 & 11,99306 \\
Valid N (listwise) & 68 & & & & \\
\hline \multicolumn{2}{l}{ Sumber: Hasil olahan data penelitian, (2017) }
\end{tabular}

Variabel Human Capital Efficiency (HCE) sebagai proksi nilai modal manusia memiliki nilai paling rendah sebesar -2,1068 dan nilai terbesar yang diperoleh yakni 19,7318. Untuk rata- rata sebesar 2,587424 dengan standar deviasi 2,8558642 yang berarti terjadi perbedaan nilai HCE yang dihasilkan dengan nilai rata-rata kesuluruhan terjadi perbedaan sebesar 2,8558642. Variabel modal fisik yang diproksi oleh Capital Employed Efficiency (CEE) memiliki nilai paling rendah sebesar $-0,3572$ dan nilai terbesar CEE dengan nilai 1,4296. Nilai rata- rata yang didapatkan oleh $\mathrm{CEE}$ yaitu sebesar 0,341138. Standar deviasi sebesar 0,3226475 dengan arti terdapat perbedaan antara nilai CEE dengan nilai 
rata-rata CEE sebesar 0,3226475. Variabel modal struktural yang diproksi Structural Capital Efficiency (SCE) memiliki nilai terendah sebesar -2,2397 dan nilai tertinggi dari variabel SCE yakni 2,0704. Nilai rata- rata yang dihasilkan variabel SCE yaitu sebesar 0,421950 dengan nilai standar deviasi sebesar 0,5555788. Standar deviasi mengindikasikan terdapat perbedaan nilai SCE dengan nilai rata-ratanya sebesar 0,5555788 . Nilai minimum yang dimiliki oleh variabel VAIC $^{\text {TM }}$ sebagai proksi nilai tambah intellectual capital sebesar -1,7684 dan nilai maksimum yang diperoleh yaitu sebesar 21,0910 Nilai rata-rata variabel VAIC ${ }^{\text {TM }}$ yaitu senilai 3,350500 dengan standar deviasi sebesar 3,0466651 yang berarti terdapat perbedaan antara nilai VAIC $^{\text {TM }}$ dengan nilai rata-ratanya sebesar 3,0466651. Variabel kinerja keuangan yang diproksi ROE memiliki nilai terendah $-52,62$ dan nilai tertinggi yaitu sebesar 35,13 . Rata-rata nilai ROE yaitu sebesar 5,8109 dengan nilai standar deviasi sebesar 11,99306 yang berarti terdapat perbedaan sebesar 11,99306 antara nilai ROE dengan nilai rata-ratanya.

Tabel 3. Hasil Uji Normalitas

\begin{tabular}{lc}
\hline & $\begin{array}{c}\text { Unstandardized } \\
\text { Residual }\end{array}$ \\
\hline Asyp. Sig (2 tailed) & 0,200 \\
\hline Sumber: Hasil olahan data penelitian, (2017) &
\end{tabular}

Tabel 3 melaporkan nilai signifikansi variabel yaitu $0,200>0,05$, disimpulkan variabel modal manusia (HCE), modal fisik (CEE), modal struktural (SCE) dan ROE sebagai proksi kinerja keuangan berdistribusi normal.

Tabel 4. Hasil Uji Multikolinearitas

\begin{tabular}{cccc}
\hline No. & Variabel & Tolerance & VIF \\
\hline 1. & HCE & 0,899 & 1,112 \\
2. & CEE & 0,925 & 1,081 \\
3. & SCE & 0,841 & 1,189 \\
\hline
\end{tabular}

Sumber: Hasil olahan data penelitian, (2017) 
Berdasarkan pengujian SPSS tabel Uji diatas menunjukkan nilai tolerance dari setiap variabel independen yaitu HCE,CEE dan SCE lebih besar dari 0,10 dan nilai VIF berada dibawah angka 10 sehingga dapat disimpulkan bahwa model yang diregresikan bebas dari adanya multikolinearitas.

Tabel 5. Hasil Uji Heterokedastisitas

\begin{tabular}{llll}
\hline No. & \multicolumn{1}{c}{ Variabel } & Sig & \multicolumn{1}{c}{ Keterangan } \\
\hline 1. & HCE (X1) & 0,187 & Homokedastisitas \\
2. & CEE (X2) & 0,899 & Homokedastisitas \\
3. & SCE (X3) & 0,584 & Homokedastisitas \\
\hline \multicolumn{2}{l}{ Sumber: Hasil olahan data penelitian, (2017) }
\end{tabular}

Berdasarkan laporan hasil SPSS pada Tabel 5 menunjukkan seluruh nilai signifikansi variabel independen atau variabel bebas dari model regresi lebih besar dari nilai taraf signifikansi penelitian $(0,05)$, dapat disimpulkan bahwa data tersebut bebas dari gejala heterokedastisitas.

Tabel 6. Hasil Uji Autokorelasi

\begin{tabular}{|c|c|c|c|c|c|}
\hline Model & $\mathbf{R}$ & $\begin{array}{c}\mathbf{R} \\
\text { Square }\end{array}$ & $\begin{array}{l}\text { Adjusted } \\
\text { R Square }\end{array}$ & $\begin{array}{l}\text { Std. Error of } \\
\text { the Estimate }\end{array}$ & $\begin{array}{l}\text { Durbin.- } \\
\text { Watson }\end{array}$ \\
\hline 1 &, $662^{\mathrm{a}}$ & ,439 & ,413 & 9,19231 & 1,731 \\
\hline
\end{tabular}
diperlukan adanya Uji Autokorelasi untuk mengetahui apakah terdapat korelasi antara variabel penelitian pada perbedaan tahun. Berdasarkan Tabel 6 tersebut nilai D-W sebesar 1,731. Persamaan Regresi ini memiliki (n) data sebanyak 68 dan $(\mathrm{k})$ variabel independen berjumlah 3 , didapatkan nilai $\mathrm{d}_{\mathrm{L}}=1,52$ dan $\mathrm{d}_{\mathrm{U}}=1,70$ dari tabel Uji Durbin-Watson sehingga $4-\mathrm{d}_{\mathrm{L}}=2,30$ dan $4-\mathrm{d}_{U}=2,48$. Nilai Durbin Watson pada persamaan regresi yaitu 1,731 berada di tengah nilai du dan 4-du, 
$(1,70<1,731<2,30)$ hal ini mengindikasikan bahwa model yang diregresikan berada pada daerah bebas dari korelasi.

Tabel 7. Hasil Analisis Regresi Linier Berganda

\begin{tabular}{|c|c|c|c|c|c|}
\hline \multirow[t]{2}{*}{ Model } & \multicolumn{2}{|c|}{$\begin{array}{l}\text { Unstandardized } \\
\text { Coefficients }\end{array}$} & \multirow{2}{*}{$\begin{array}{c}\begin{array}{c}\text { Standardized } \\
\text { Coefficients }\end{array} \\
\text { Beta }\end{array}$} & \multirow[t]{2}{*}{$\mathbf{T}$} & \multirow[t]{2}{*}{ Sig. } \\
\hline & B & $\begin{array}{l}\text { Std. } \\
\text { Error }\end{array}$ & & & \\
\hline 1 (Constan) & $-7,069$ & 2,196 & & $-3,220$ & ,002 \\
\hline HCE & 1,635 & ,415 & ,389 & 3,944 & ,000 \\
\hline CEE & 20,871 & 3,619 & ,561 & 5,767 & ,000 \\
\hline SCE & 3,622 & 2,204 &, 168 & 1,644 &, 105 \\
\hline R Square $=$ & 0,439 & & & $\mathrm{~F}=$ & 16,682 \\
\hline Adj R. Square = & 0,413 & & & $\operatorname{Sig}=$ & 0,000 \\
\hline
\end{tabular}

Sumber: Hasil olahan data penelitian, (2017)

Berdasarkan Tabel 7, diperoleh persamaan garis linier berganda yakni:

$$
Y=-7,069+1,635 X_{1}+20,871 X_{2}+3,622 X_{3}
$$

Nilai koefisien regresi Human Capital Efficiency (HCE) sebesar 1,635 yang berarti apabila nilai HCE meningkat sebesar 1 satuan nilai maka nilai ROE akan meningkat sebesar 1,635 persen dengan asumsi bahwa variabel lain dianggap stabil atau konstan. Nilai koefisien regresi Capital Employed Efficiency (CEE) sebesar 20,871 yang memiliki arti bahwa setiap kenaikan 1 satuan CEE akan meningkatkan nilai ROE sebesar 20,871 persen dengan asumsi bahwa variabel lain dianggap stabil ataupun konstan. Nilai koefisien regresi Structural Capital Efficiency (SCE) sebesar 3,622 memiliki arti setiap peningkatan 1 satuan SCE akan meningkatkan nilai ROE sebesar 3,622 persen namun dengan asumsi bahwa variabel lain konstan.

Dengan nilai Uji F signifikansinya sebesar 0,000 $<0,05$ memiliki arti bahwa model regresi layak dalam mengukur variabel kinerja keuangan (ROE). Koefisien determinasi $\left(\mathrm{R}^{2}\right)$ menginformasikan seberapa besar variabel independen dapat 
menjelaskan besaran nilai dari variabel dependen. Pada tabel 7 memperlihatkan bahwa besarnya nilai Adjusted $R$ Square adalah sebesar 0,413, ini artinya variabel dalam model regresi tersebut yaitu Human Capital Efficiency (HCE), Capital Employed Efficiency (CEE) dan Structural Capital Efficiency (SCE) dapat menjelaskan variabel ROE sebesar 41,3 persen sedangkan sisanya yakni 58,7 persen dipengaruhi oleh faktor-faktor lain yang tidak termasuk dalam model regresi.

Tabel 8. Ringkasan Hasil Statistik Uji t

\begin{tabular}{|c|c|c|c|c|c|}
\hline No. & Variabel & Koefisien Regresi & $t_{\text {hitung }}$ & Sig. & $t_{\text {tabel }}$ \\
\hline 1 & HCE & 1,635 & 3,944 &, 000 & 1,669 \\
\hline 2 & CEE & 20,871 & 5,767 & , 000 & 1,669 \\
\hline 3 & SCE & 3,622 & 1,644 & , 105 & 1,669 \\
\hline
\end{tabular}

Uji t dipergunakan dalam mengetahui pengaruh variabel secara parsial terhadap variabel dependen. Pengaruh Human Capital Efficiency (HCE) terhadap ROE. Pengaruh modal manusia yang diproksikan dengan Human Capital Efficiency (HCE) terhadap ROE secara parsial dilihat dari Tabel 8 diketahui thitung sebesar 3,944 yang diperoleh dari hasil olahan spss lebih besar dari tabel $=(\alpha ; n-k)$ $=\mathrm{t}_{(0,05 ; 64)}$ yaitu sebesar 1,669. Dengan hasil tersebut $\mathrm{t}_{\text {hitung }}$ berada pada daerah penolakan $\mathrm{H}_{0}$ dan level signifikansi sebesar 0,000 > 0,05. Hal ini mengindikasikan hipotesis 1 yang menyatakan bahwa Human Capital Efficiency (HCE) berpengaruh positif signifikan terhadap Return On Equity (ROE), diterima.

Pengaruh Capital Employed Efficiency (CEE) terhadap ROE. Pengaruh modal fisik yang diproksi dengan Capital Employed Efficiency (CEE) terhadap ROE secara parsial dilihat dari Tabel 8 diketahui thitung sebesar 5,767 yang 
diperoleh dari hasil olahan spss lebih besar dari $\mathrm{t}_{\text {tabel }}=(\alpha ; n-\mathrm{k})=\mathrm{t}_{(0,05 ; 64)}$ yaitu sebesar 1,669. Dengan hasil tersebut thitung berada pada daerah penolakan $\mathrm{H}_{0}$ dan level signifikansi sebesar $0,000>0,05$. Hal ini mengindikasikan hipotesis 2 yang menyatakan bahwa Capital Employed Efficiency (HCE) berpengaruh positif signifikan terhadap Return On Equity (ROE), diterima.

Pengaruh modal struktural yang diproksikan dengan Structural Capital Efficiency (HCE) terhadap ROE secara parsial dilihat dari Tabel 8 diketahui thitung sebesar 1,644 yang diperoleh dari hasil olahan spss lebih kecil dari $\mathrm{t}_{\text {tabel }}=(\alpha ; \mathrm{n}-\mathrm{k})$ $=\mathrm{t}_{(0,05 ; 64)}$ yaitu sebesar 1,669. Dengan hasil tersebut $\mathrm{t}_{\text {hitung }}$ berada pada daerah penerimaan $\mathrm{H}_{0}$ dan level signifikansi sebesar $0,105>0,05$. Hal ini mengindikasikan hipotesis 3 yang menyatakan bahwa Structural Capital Efficiency (SCE) berpengaruh positif signifikan terhadap Return On Equity (ROE), ditolak.

Pengaruh Value Added Intellectual Coefficient (VAICTM). Pengaruh modal intelektual secara keseluruhan yang diproksikan dengan nilai tambah VAIC ${ }^{\text {TM }}$ terhadap ROE diukur dengan uji $\mathrm{F}$ dilihat dari Tabel 8 diketahui nilai $\mathrm{F}$ hitung sebesar 16,682 yang diperoleh dari hasil olahan spss dengan level signifikansi sebesar $0,000>0,05$. Hal ini mengindikasikan hipotesis 4 yang menyatakan bahwa Value Added Intellectual Coefficient (VAICTM) berpengaruh positif signifikan terhadap Return On Equity (ROE), diterima.

Hasil penelitian menunjukkan HCE berpengaruh positif signifikan terhadap ROE pada perusahaan subsektor Hotel, Restoran dan Pariwisata periode tahun 2012-2015. Penelitian ini sesuai dengan penelitian Ting et al., (2009) pada 
perusahaan sektor perbankan di Malaysia menunjukan modal manusia memiliki peranan dalam meningkatkan kinerja keuangan perusahaan. Ditemukan pula dalam penelitian yang dilakukan oleh Kamal et al., (2012) pada industri perbankan di Malaysia, hasil lainnya yaitu Muthater dan Prasetyo (2014) juga mengindikasikan hasil yang sama. Dari hasil pengaruh yang positif signifikan ini mengindikasikan bahwa variabel HCE mengindikasikan termasuk dalam faktor utama yang dapat mempengaruhi kinerja keuangan secara signifikan.

Human capital efficency (HCE) adalah elemen penting dalam penciptaan nilai tambah dari intellectual capital dalam sebuah perusahaan. Berbeda dengan modal struktural, modal manusia ini dimiliki oleh tiap elemen individu yang dimiliki oleh perusahaan paling tidak dapat memaksimalkan prosedur dan struktur dalam organisasi guna menopang kegiatan (Kamal et al., 2012). Menurut Bontis et al., (2015) pengetahuan adalah elemen yang kuat dalam menciptakan keunggulan kompetitif terutama pada era globalisasi. Dimana kinerja keuangan pada perusahaan subsektor hotel, restoran dan pariwisata di BEI pada tahun 20122015 pada penelitian ini membuktikan pengaruh yang signifikan dari variabel HCE dimana dalam subsektor ini produk yang dimiliki dominan mengenai jasa atau barang tak berwujud yang tentunya dihasilkan dari modal manusia yang dihitung dari HCE. Hal ini sesuai dengan teori RBV yang dinyatakan oleh Wernelfelt (1998) bahwa apabila perusahaan dapat memegang, mengontrol dan mempergunakan aset serta modal yang strategis maka dapat meningkatkan persaingan terutama pada industri yang sama, dimana modal manusia dalam subsektor ini termasuk dalam modal yang strategis. 
Hasil penelitian menunjukkan capital employed efficiency (CEE) berpengaruh positif signifikan terhadap ROE pada perusahaan subsektor Hotel, Restoran dan Pariwisata periode tahun 2012-2015. Penelitian dengan hasil yang sama yaitu penelitian oleh Bontis et al., (2015) pada Industri Hotel di Serbia; Aritonang dkk. (2016) pada perusahaan non bank Indonesia di BEI, serta Muthather dan Prasetyo (2014) pada perusahaan manufaktur di BEI. Dari hasil pengaruh yang positif signifikan ini mengindikasikan bahwa variabel CEE termasuk dalam faktor utama yang dapat mempengaruhi kinerja keuangan yang diproksi ROE secara signifikan.

Perusahaan yang dapat memperoleh kinerja keuangan yang baik jika sukses dalam mengelola sumber daya yang dimilikinya dan menghasilkan keunggulan kompetitif (Rambe, 2012). Modal fisik adalah modal perusahaan yang berupa dana keuangan serta aset yang bersifat fisik yang dipergunakan dan dapat meningkatkan nilai tambah (Wiradinata dan Siregar, 2011). Sumber daya fisik dan sumber daya finansial ini sangat memiliki peranan penting dalam peningkatan kinerja keuangan. Modal fisik sangat berperan penting dalam kegiatan operasi sebuah perusahaan selain sebagai penunjang pekerjaan juga sebagai salah satu faktor peningkatan laba dari ekuitas maupun aset yang dimiliki oleh sebuah perusahaan. Dari hasil penelitian ini dapat disimpulkan kinerja keuangan subsektor ini signifikan dipengaruhi oleh modal fisik dimana gedung perhotelan serta bahan makanan pada restoran adalah salah satu penopang dalam kegiatan bisnis pariwisata. 
Wayan Anggara Wijaya, Pengaruh Intellectual Capital Terhadap...

Hasil penelitian menunjukkan structural capital efficency (SCE) berpengaruh positif tidak signifikan terhadap return on equity (ROE) pada perusahaan subsektor Hotel, Restoran dan Pariwisata periode tahun 2012-2015. Hasil yang sama dihasilkan oleh Kamal et al., (2012), Salim dan Karyawati (2013), dan penelitian yang dilakukan oleh Bontis et al., (2015) bahwa SCE tidak berpengaruh signifikan terhadap kinerja keuangan. SCE bukan termasuk dalam faktor utama dalam mempengaruhi kinerja keungan.

Hasil mengindikasikan structural capital efficiency memiliki arah pengaruh yang positif terhadap kinerja keuangan namun tidak signifikan dapat meningkatkan kinerja keuangan perusahaan subsektor hotel, restoran dan pariwisata. Tidak signifikannya pengaruh langsung yang dihasilkan karena modal struktural pada subsektor ini memerlukan modal fisik lainnya sebagai penopang nilai tambah dalam kinerja keuangan perusahaan. Menurut Salim dan Karyawati (2013) hal ini dikarenakan perusahaan belum dapat memanfaatkan modal struktural yaitu proses rutinitas perusahaan dalam menghasilkan keunggulan bersaing yag bermanfaat bagi kinerja keuangan perusahaan.

Hasil penelitian menunjukkan value added intellectual coefficient (VAIC ${ }^{\mathrm{TM}}$ ) sebagai proksi intellectual capital secara keseluruhan dalam perusahaan berpengaruh positif signifikan terhadap return on equity (ROE) pada perusahaan subsektor Hotel, Restoran dan Pariwisata di Bursa Efek Indonesia pada tahun 2012-2015. Penelitian lain yang sesuai dengan hasil tersebut yakni penelitian Tan et al., (2007), Kharal et al., (2014) serta Gozali \& Hatane (2014) juga menemukan hal yang sama dimana VAIC ${ }^{\text {TM }}$ memiliki pengaruh positif dan signifikan terhadap 
ROE. Dari hasil pengaruh positif signifikan ini mengindikasikan bahwa variabel VAIC $^{\text {TM }}$ termasuk dalam faktor utama yang dapat mempengaruhi ROE secara signifikan.

Menurut Kweh et al., (2013) Nilai tambah yang dihasilkan oleh IC dimulai dari informasi-informasi yang disusun menjadi pengetahuan, dan pengetahuan yang didapatkan tersebut yang ditranformasikan menjadi intellectual capital. Perhitungan VAIC ${ }^{\text {TM }}$ mencakup nilai tambah yang dihasilkan dari sumberdaya strategis perusahaan sehingga pengaruh yang dihasilkan dapat meningkatkan kinerja keuangan perusahaan. Perusahaan dapat memperoleh kinerja keuangan yang baik jika sukses dalam mengelola sumber daya yang dimilikinya. (Rambe, 2012). Hasil penelitian ini memberikan informasi bagi perusahaan untuk mengetahui peranan yang dimiliki oleh sumber daya strategis di perusahaan terutama intellectual capital. Hal ini diperkuat dengan subsektor hotel, restoran dan pariwisata yang dimana memiliki produk yang dominan tak berwujud. Dengan pengelolaan yang baik, nilai tambah yang dihasilkan intellectual capital dalam memanfaatkan sumber daya lainnya di perusahaan dapat memberikan pengaruh positif bagi kinerja keuangan perusahaan.

\section{SIMPULAN DAN SARAN}

Komponen modal manusia berpengaruh positif signifikan terhadap kinerja keuangan (ROE) pada perusahan subsektor Hotel, Restoran dan Pariwisata di BEI. Hal ini berarti modal manusia yang dimiliki dapat dimanfaatkan secara efektif dan efisien untuk menunjang pekerjaan operasinal perusahaan. Dengan adanya upaya 
peningkatan kemampuan berpikir individu, pelatihan dan pengembangan manusia yang dilakukan dapat meningkatkan kinerja keuangan perusahaan.

Komponen modal fisik berpengaruh positif signifikan terhadap kinerja keuangan (ROE) pada perusahaan subsektor Hotel, Restoran dan Pariwisata di BEI. Hal ini berarti permasalahan mengenai kinerja keuangan dapat diatasi salah satunya dengan memperhatikan modal fisik yang dimiliki. Efisiensi yang dihasilkan dari penggunaan modal fisik harus terus diperhatikan perusahaan karena terbukti dapat meningkatkan kinerja keuangan perusahaan.

Komponen modal struktural berpengaruh positif tidak signifikan terhadap kinerja keuangan (ROE) pada subsektor Hotel, Restoran dan Pariwisata di BEI. Hal ini berarti modal struktural belum memiliki kontribusi yang tinggi terhadap kinerja keuangan perusahaan. Pemanfaatan modal struktural dalam perusahaan tersebut belum dapat mempengaruhi kinerja keuangan perusahaan. Hal ini dikarenakan belum ada kuantitas yang tinggi dalam penggunaan modal struktural saat kegiatan operasional perusahaan sehingga modal struktural ini belum dapat denganbaik mempengaruhi kinerja keuangan perusahaan.

VAIC $^{\text {TM }}$ yang mencerminkan intellectual capital yang dimiliki perusahaan subsektor Hotel, Restoran dan Pariwisata berpengaruh positif signifikan terhadap kinerja keuangan perusahaan. Hal ini berarti pemanfaatan intellectual capital dalam perusahaan memiliki pengaruh terhadap kinerja keuangan perusahaan tersebut. Ini mengindikasikan bahwa perusahaan subsektor ini dapat mengkombinasikan dengan baik modal intelektual yang dimiliki perusahaan. 
Berdasarkan simpulan yang dikemukakan, terdapat beberapa saran yang sehubungan dengan penelitian yaitu bagi peneliti selanjutnya mengenai kinerja keuangan perusahaan dapat menggunakan referensi intellectual capital sebagai indikator yang memiliki hubungan dengan kinerja keuangan, dan dapat menambah variabel lain dalam variabel independen untuk mengetahui pengaruh yang lebih besar dalam menjelaskan kinerja keuangan perusahaan.

Penelitian empiris ini membuktikan bahwa manajer dalam perusahaan perlu meningkatan efisiensi penggunaan modal struktural dengan memperbanyak penggunaannya pada kegiatan operasional sehari-hari perusahaan yaitu seperti sistem yang dimiliki, perangkat lunak komputer, layanan internet atau penunjang pekerjaan manusia selain modal fisik dalam meningkatkan pengaruhnya terhadap kinerja keuangan perusahaan.

\section{REFERENSI}

Arifin, Jauhar. (2016). Pengaruh Intelektual Kapital Terhadap Kinerja Keuangan Pada Perusahaan Sector Perbankan yang Terdaftar di Bursa Efek Jakarta Periode 2008-2012. Jurnal AdBispreneur, 1 (3), 195-206.

Aritonang, Qaharuna Agasa Setyadam., Harjum Muharam, dan Sugiono. (2016). Pengaruh Intellectual Capital Terhadap Kinerja Keuangan (Studi Pada Perusahaan Non Keuangan yang Terdaftar di Bursa Efek Indonesia Tahun 2012-2014. Jurnal Bisnis Strategi, 25 (1), 49-64.

Belkaoui, Ahmed Riahi. (2003). Intellectual Capital and Firm Performance of US Multinational Firm: A Study of The Resource-Based and Stakeholder View. Journal of Intellectual Capital, 4 (2), 215-226.

Bontis, Nick., Stevo Janošević and Vladimir Dženopoljac. (2015). Intellectual Capital in Serbia's Hotel Industry. Internatinal Journal of Temporary Hospitality Management, 27 (6), 1365-1384. 
Brooking, Annie. (2010). On The Importance of Managing Intangible Assets As Part of Corporate Strategy. Electronic Journal of Knowledge Management, 8 (2), 217-224.

Budihardjo, Andreas. (2016). Knowledge Management: Efektif Berinovasi Meraih Sukses. Cetakan pertama. Jakarta : Prasetiya Mulya Publishing.

Bursa Efek Indonesia pada website www.idx.co.id (diunduh pada tanggal 20 mei 2017).

Chen, M.C., S.J Cheng and Y. Hwang. (2005). An Empirical Investigation of Relationship Between Intellectual Capital and Firms Market Value and Financial Performance. Journal of Intellectual Capital, 6 (2), 159-176.

Ciptaningsih, Tri. (2013). Uji Pengaruh Modal Intelektual Terhadap Kinerja Keuangan BUMN yang Go Public di Indonesia. Jurnal Manajemen Teknologi, 13 (3), 2089-7928.

Edvinsson, L. (1997). Developing Intellectual Capital in Skandia. Long Range Planning, 30 (3), 266-373.

Gozali, Adrian dan Saarce Elsye Hatane. (2014). Pengaruh Intellectual Capital Terhadap Kinerja Keuangan dan Nilai Perusahaan Khususnya di Industri Keuangan dan Industri Pertambangan yang Terdaftar di Bursa Efek Indonesia tahun 2008-2012. Business Accounting Review, 2 (2), 208-217.

Grant, R.M. (1991). The Resource-Based Theory of Competitive Advantage: Implications for Strategy Formulation. California Management Review. 33 (3), 114-135.

Halim, Abdul. (2015). Manajemen Keuangan Bisnis. Edisi pertama. Jakarta: Mitra Wacana Media.

Irene Wei Kiong Ting and Hooi Hooi Lean. (2009). Intellectual Capital Performance of Financial Institutions in Malaysia. Journal of Intellectual Capital, 10 (4), 588-599.

Kamal, Malina Hanum Mohd., Rosfatihah Che Mat, Najihah Abdul Rahim, Norhusniyati Husin, and Irwan Ismail. (2012). Intellectual Capital and Firm Performance of Comercial Bank In Malaysia. Asian Economic and Financial, 2 (4), 577-590.

Kanchana, N and Prof. R.R. Raja Mohan. (2017). A Review of Empirical Studies in Intellectual Capital and Firm Performances. Indian Journal of Commerce \& Management Studies, 8 (1), 52-58. 
Khalique, Muhammad., Jamal Abdul Nassir bin Shaari, Abu Hassan bin Md. Isa and Noridah binti Samad. (2013). Impact of Intellectual Capital on The Organizational Performance of Islamic Banking Sector in Malaysia. Asian Journal of Finance and Accounting, 5 (2), 75-83.

Kweh, Qian Long., Yee Chuann Chann and Irene Wee Kiong Ting. (2013). Measuring Intellectual Capital Efficiency In The Malaysian Sofware Sector. Journal of Intellectual Capital, 14 (2), 310-324.

Madhani, Pankaj M. (2010). Resource Based View (RBV) of Competitive Advantage: An Overview. http://ssrn.com/abstract=1578704 (diunduh tanggal 15 Mei 2017).

Muthaher, Osmad dan Iwan Nur Prasetya. (2014). Pengaruh Modal Intelektual Terhadap ROE dan EPS sebagai Proksi Kinerja Keuangan. Jurnal EKOBIS, 15 (2), 71-85.

Ozkan, Nasif., Cakan, S. and Kayacan, M. (2016). Intellectual Capital and Financial Performance: A Study of Turkish Banking Sector. Borsa Istanbul Review $x x, 1-9$.

Pramelasari, Y. M. (2010). Pengaruh Intellectual Capital Terhadap Nilai Pasar dan Kinerja Keuangan. Skripsi Sarjana Akuntansi pada Fakultas Ekonomi Universitas Diponegoro, Semarang.

Pulic, A. (1998). Measuring The Performance of Intellectual Potential in Knowledges Economy. Paper presented at the 2nd McMaster World Congress on Measuring and Managing Intellectual Capital, Hamilton.

Pulic, A. (2004). Intellectual Capital: Does It Create or Destroy Value?. Measuring Business Excellent, 8 (1), 62-68.

Ramadhani, Febriyanti., Reka Maiyarni, dan Nela Safelia. (2014). Pengaruh Modal Intelektual Terhadap Kinerja Keuangan Perusahaan Perbankan yang Terdaftar di Bursa Efek Indonesia (BEI) Tahun 2010-2012. Jurnal Cakrawala Akuntansi, 6 (2), 126-134.

Rambe, Rizki Fillhayati. (2012). Pengaruh Intellectual Capital Terhadap Kinerja Keuangan Perusahaan Perbankan yang Terdaftar Di BEI. Jurnal Keuangan Dan Bisnis, 4 (3), 239-246.

Rupidara, Neil. (2008). Modal Intelektual dan Strategi Pengembangan Organisasi dan Sumber Daya Manusia. Paper disajikan pada Diskusi Modal Intelektual $I K S W$, Salatiga. 
Rusmalia Dewi, Nuraisyah dan Setyowati Arum. (2015). Analisis Pengaruh Modal Intelektual Terhadap Kinerja Keuangan. Fokus Manajerial, 13 (2), 133-146.

Salim, Selvi Meliza dan Golrida Karyawati. (2013). Pengaruh Modal Intelektual Terhadap Kinerja Keuangan. Journal Of Business and Entrepreneurship, 1 (2), 74-91.

Subkhan dan Dyah Pitaloka Citraningrum. (2010). Pengaruh IC Terhadap Kinerja Keuangan Perusahaan Perbankan Periode 2005-2007. Jurnal Dinamika Akuntansi, 2 (1), 30-36.

Tan, Hong Pew., David Plowman and Phil Hancock. (2007). Intellectual Capital and Financial Returns of Companies. Journal of Intellectual Capital, 8 (1), 76-95.

Tjiptohadi Sawarjuwono dan Agustine Prihatin Kadir. (2003). Intellectual Capital : Perlakuan, Pengukuran dan Pelaporan (sebuah library research). Jurnal Akuntansi \& Keuangan, 5 (1), 35-57.

Wahdikorin, Ayu. (2010). Pengaruh Modal Intelektual Terhadap Kinerja Keuangan Perusahaan Perbankan yang Terdaftar di Bursa Efek Indonesia (BEI) Tahun 2007-2009. Skripsi Sarjana Akuntansi pada Fakultas Ekonomi Universitas Diponegoro, Semarang.

Wernerfelt, Birger. (1984). A Resource Based View of The Firm. Strategic Management Journal, 5 (2), 171-180.

Wiagustini, Ni Luh Putu. (2014). Manajemen Keuangan. Denpasar: Udayana University Press

Wijaya, Shearly Putri. (2012). Pengaruh Intellectual Capital Terhadap Profitabilitas Pada Perusahaan Farmasi di BEI. Jurnal Ilmiah Mahasiswa Akuntansi, 1 (3), 18-23.

Wiradinata, Jeffry dan Siregar Baldrig. (2011). Pengaruh Modal Intelektul terhadap Kinerja Keuangan Pada Perusahaan Sektor Keuangan Yang Terdapat di Bursa Efek Indonesia. Jurnal Akuntansi \& Manajemen, 22 (2), 107-124.

Yalama, A. (2013). The Relationship Between Intellectual Capital and Banking Performance in Turkey: Evidence From Panel Data. International Journal Of Learning And Intellectual Capital, 10 (1), 71-87. 
E-Jurnal Manajemen Unud, Vol. 7, No. 2, 2018: 701-729

Zhegal, D. and Maaloul, A. (2010). Analyzing Value Added As An Indicator of Intellectual Capital and It Concequences on Company Performance. Journal of Intellectual Capital, 11 (1), 39-60. 